\title{
MENINGKATKAN KETERAMPILAN BERBAHASA ANAK MELALUI FLIPPED LEARNING
}

\author{
Irfan Fajrul Falah \\ Program Studi Pendidiksn Guru Sekolah Dasar, STKIP Muhammadiyah Kuningan \\ E-mail: irfan_fajrul@upmk.ac.id
}

Falah, Irfan Fajrul., (2021). Meningkatkan Keterampilan Berbahasa Anak Melalui Flipped Learning. Jurnal Pelita PAUD, 6(1), 141-147.

doi: https://doi.org/10.33222/pelitapaud.v6i1.1439

\begin{abstract}
Abstrak: Pandemi Covid-19 memberikan dampak yang sangat besar terutama bagi pendidikan. Pendidikan anak usia dini tidak terlepas dari hal tersebut, dimana mayoritas guru tidak bisa berinteraksi secara intens di dalam kelas seperti sebelumnya. Ditengah keterbatasan tersebut, guru dituntut untuk mengkesplorasi kreatifitas mereka agar proses pembelajaran senantiasa bisa berjalan. Salah satu pendekatan pembelajaran yang dapat digunakan adalah model flipped learning dimana model ini mengkombinasikan antara pembelajaran daring dan juga tatap muka. Tujuan dari penelitian ini adalah untuk melihat sejauh mana efektifitas flipped learning dalam meningkatkan keterampilan berbahasa siswa khususnya berbicara. Metode yang digunakan dalam penelitian ini adalah design based research dimana guru mendesain pembelajaran yang akan dilakukan serta melakukan intervensi atau tindakan tertentu agar mendapatkan hasil yang maksimal dari sebuah proses pembelajaran. Adapun hasil dari penelitian ini adalah terjadi peningkatan keterampilan berbahasa anak setelah menggunakan pendekatan flipped learning.
\end{abstract}

Kata kunci: flipped learning, desain, usia dini

Abstract: Covid-19 pandemic has affected many aspects particularly in education. Early childhood education is in the same position where majority of the teachers are unable to interact with the students intensively due to restriction. Therefore, the teachers are forced to find the relevant model thus the teaching and learning can take place. One of the model that can be implemented is flipped learning where it combines online and offline learning. this study aimed at flipped learning effevetivity in improving students linguistic skill especially speaking. The method that employed is design-based research where the teacher have the rights to design and give intervention to maximize the students' achivement. The result shows that there is an improvement on students' speaking skill after flipped learning is implemented.

Keywords: flipped learning, design, early childhood 


\section{PENDAHULUAN}

Penyebaran Corona Virus Disease atau yang lebih dikenal dengan Covid-19 memberikan dampak yang sangat besar terhadap setiap aspek kehidupan tidak terkecuali pendidikan. Hal tersebut terlihat dari berubahnya mode pembelajaran pada institusi pendidikan di semua level (SD, SMP, SMA dan Pergururuan tinggi) yang biasa dilakukan secara tatap muka dengan intensitas yang padat menjadi blended dimana pembelajaran online dipadukan dengan tatap muka yang terbatas (Sun et al., 2020). Kebijakan tersebut diambil bukan tanpa alasan, melainkan untuk menekan jumlah penyebaran virus yang masih harus dikendalikan (Kemendikbud, 2020). Pandemi covid 19 membuat siswa melakukan pembelajaran secara blanded (Sutarna et al., 2022).

Salah satu pendekatan yang relevan dimana pembelajaran online dan tatap muka bisa dilakukan adalah dengan menggunakan flipped learning (Bergmann \& Sams, 2012; Bergmann \& Sams, 2015; Flipped Learning Network, 2014). Flipped learning sendiri memang identik dengan pola pembelajaran yang dibalik dimana materi atau bahan ajar disampaikan terlebih dahulu melalui video lecturing ataupun jenis lain atau disebut preclass activity agar memberikan kesempatan kepada siswa untuk memahami materi tersebut sesuai dengan kemampuan dan juga waktu yang siswa miliki (Ozdamli \& Asiksoy, 2016; Tao, 2016) yang tentu dibantu juga oleh orang tua masing-masing di rumah.

Untuk level secondary dan tertiary education, dampak penggunaan pendekatan flipped learning ini sudah terbukti bisa meningkatkan prestasi siswa (Lai \& Hwang, 2016), keterlibatan siswa (Smallhorn, 2017); Jamaludin \& Osman, 2014) dan juga memotivasi siswa (Alsobaie, 2018) untuk memaksimalkan potensi yang dimiliki. Walaupun demikian, pada level primary education khususnya di tingkat pendidikan anak usia dini, flipped learning belum banyak disentuh oleh para guru. Hal tersebut tentu menjadikan celah yang harus diisi agar tidak terjadi ketimpangan khususnya dalam penggunaan teknologi pendidikan.

Penelitian ini bertujuan untuk mendeskripsikan bagaimana implementasi flipped learning yang dilakukan pada pendidikan anak usia dini. Dari tujuan penelitian tesebut akan terlihat apakah penggunaan flipped learning memiliki pengaruh yang signifikan atau tidak terhadap perkembangan pembelajaran anak usia dini. Adapun fokus dalam penelitian ini adalah berkaitan dengan kemampuan berbahasa terutaman berbicara anak usia 5-6 tahun dimana indikatornya adalah anak bisa mengulang kalimat sederhana, membuat pertanyaan, menyebutkan kata-kata yang dikenal, re-telling dan juga berpartisipasi dalam sebuah percakapan (Purwanti, 2011).

\section{METODE PENELITIAN}

Metode penelitian yang digunakan pada penelitian ini adalah Design Based Research (DBR) . DBR diartikan sebagai sebuah cara untuk melakukan improvisasi dan juga perubahan melalui intervensi serta perbaikan yang berkelanjutan yang dilakukan oleh guru terhadap desain pembelajaran yang dibuat agar prosesnya bisa maksimal (Hung, 2015). Dalam penelitian ini, peneliti menggunakan dua tindakan yakni tindakan atau action pertama yang berfungsi sebagai baseline atau dasar dan tindakan kedua sebagai perbaikan desain.

Penelitian ini mengambil setting di TK AlIhklas Kecamatan Cigugur tepatnya Kelas B yang berjumlah 9 siswa dimana salah satu dasar pemilihan subjek dan lokasi sendiri adalah dikarenakan di TK tersebut proses pembelajaran sudah mengkombinasikan antara pembelajaran online dan tatap muka. Pembelajaran online sendiri memang masih jauh dari ideal dimana guru dan siswa hanya difasilitasi oleh WhatsApp grup, namun tentu bisa menjangkau kebutuhan siswa akan materi yang didistribusikan oleh guru. Sementara untuk tatap muka sendiri TK Al Ikhlas menggunakan pola shifting (Sahara \& Sofya, 2020) dimana setiap angkatan memiliki kesempatan untuk berangkat ke sekolah secara bergiliran.

Mayoritas data dalam penelitian ini didapatkan melalui observasi dan juga wawancara. Adapun terkait keterampilan berbicara siswa, peneliti menggunakan performance checklist dimana indikatorindikator siswa terampil berbicara tersedia dalam checklist tersebut. Misalnya artikulasi yang jelas, kepercayaan diri, struktur kalimat 
yang baik, perbendaharaan kata yang memadai, penyampaian ide terkait materi yang dibagikan dan lain sebagainya. Peneliti sendiri memiliki peran ganda. Disatu sisi sebagai desainer yang membuat desain bahan dan juga materi yang didistribusikan kepada siswa baik itu berupa video dan juga materi yang lain. Disisi lain peneliti juga berperan sebagai pasive participant (Creswell, 2013) yang keberadaanya didalam kelas hanya untuk mengobservasi proses pembelajaran yang dilangsungkan. Proses pengajaran yang berlangsung sebanyak dua kali, diampu oleh guru / wali kelas yang tentu sudah melakukan diskusi dan juga kolaborasi sebelumnya dengan peneliti terkait teknis pembelajaran.

Data yang terkumpul khususnya tekait keterampilan berbicara siswa dianalisis secara statistik sederhana untuk melihat perkembangan keterampilan berbicara anak. Adapun indikator yang digunakan adalah sebagai berikut :

Tabel 1. Indikator penilaian

\begin{tabular}{cccc}
\hline No & $\begin{array}{c}\text { Kriteria } \\
\text { Penilaian }\end{array}$ & Nilai & Prosentase \\
\hline 1 & BSB & $76-100$ & $76-100 \%$ \\
2 & BSH & $51-75$ & $51-75 \%$ \\
3 & MB & $26-50$ & $26-50 \%$ \\
4 & BB & $0-25$ & $0-25 \%$ \\
\hline
\end{tabular}

\section{HASIL DAN PEMBAHASAN}

Penelitian ini dilakukan dengan menggunakan dua tindakan. Masing-masing tindakan terdiri dari dua pertemuan yakni pertemuan secara online dan tatap muka. Pertemuan secara online dilakukan sebagai langkah pertama guru untuk berinteraksi dengan siswa. Dalam pertemuan tersebut guru meggunakan media WhatsApp Group (WAG) yang sudah dibuat untuk mendistribusikan materi yang dapat dipelajari siswa. Pada pertemuan pertama secara online, guru memberikan video tentang makanan favorit yang tentu masih termasuk pada pengembangan tema diriku. Adapun video pembelajaran tersebut diambil dari platform yang sudah tersedia seperti di Youtube.

Salah satu pendekatan yang relevan dimana pembelajaran online dan tatap muka bisa dilakukan adalah dengan menggunakan flipped learning (Bergmann \& Sams, 2012; Bergmann \& Sams, 2015; Flipped Learning
Network, 2014). Flipped learning sendiri memang identik dengan pola pembelajaran yang dibalik dimana materi atau bahan ajar disampaikan terlebih dahulu melalui video lecturing ataupun jenis lain atau disebut preclass activity agar memberikan kesempatan kepada siswa untuk memahami materi tersebut sesuai dengan kemampuan dan juga waktu yang siswa miliki (Ozdamli \& Asiksoy, 2016; Tao, 2016) yang tentu dibantu juga oleh orang tua masing-masing di rumah.

Untuk level secondary dan tertiary education, dampak penggunaan pendekatan flipped learning ini sudah terbukti bisa meningkatkan prestasi siswa (Lai \& Hwang, 2016), keterlibatan siswa (Smallhorn, 2017); Jamaludin \& Osman, 2014) dan juga memotivasi siswa (Alsobaie, 2018) untuk memaksimalkan potensi yang dimiliki. Walaupun demikian, pada level primary education khususnya di tingkat pendidikan anak usia dini, flipped learning belum banyak disentuh oleh para guru. Hal tersebut tentu menjadikan celah yang harus diisi agar tidak terjadi ketimpangan khususnya dalam penggunaan teknologi pendidikan.

Hal ini dilakukan untuk melihat respon siswa terhadap video pembelajaran yang tidak dikembangkan oleh gurunya sendiri. Selain memberikan video pembelajaran, dalam WAG tersebut guru juga meminta siswa untuk mencoba mengungkapkan makanan atau minuman favorit masing-masing tanpa merekam video hanya dilatihkan di rumah/tempat masing-masing dan dibantu oleh orang tua siswa. Adapun redaksi penyampaian bisa sesuai dengan video ataupun improvisasi dari siswa. Hal ini dilakukan agar pada pertemuan tatap muka siswa sudah memiliki dasar berkaitan dengan apa yang akan dibicarakan.

Pada pertemuan tatap muka, seperti biasa guru meyambut siswa dengan senyuman dan juga mengucapkan salam. Setelah kegiatan pendahuluan tersebut selesai dilakukan termasuk berdoa dan juga bernyanyi, guru mengajak siswa berbincang tentang video pembelajaran yang diberikan pada kesempatan sebelumnya sebagai bentuk stimulus (Bergmann \& Sams, 2015) dan juga bertanya kepada siswa apakah mereka berlatih mengungkapkan apa yang minta oleh guru atau tidak. Dari 9 siswa rata-rata sudah bisa 
berpartisipasi secara lisan dalam kegiatan tersebut yang juga merupakan bagian dari proses pembelajaran. Berdasarkan observasi yang dilakukan, terdapat 2 siswa yakni SW dan juga AF yang aktif dalam berbicara baik bertanya ataupun menjawab. Sementara siswa yang lain relatif sebagai partisipan dan hanya menjawab ketika diberikan kesempatan oleh guru.

Setelah guru selesai dengan stimulus yang dilakukan, kegiatan berikutnya adalah memberikan kesempatan kepada setiap siswa untuk berbicara tentang makanan dan minuman favorit masing-masing. pada kesempatan ini, peneliti melakukan proses penilaian yang didasarkan pada aspek-aspek sebagai berikut :

Kepercayaan diri (K), Artikulasi (A), Diksi (D), Ide / Gagasan (I), Respon (R)

Berdasarkan hasil pengamatan yang dilakukan didapatkan hasil sebagai berikut :

Tabel 2. Keterampilan berbicara siswa pada tindakan pertama

\begin{tabular}{lllcccccc}
\hline $\begin{array}{l}\mathrm{N} \\
\text { o }\end{array}$ & $\begin{array}{l}\text { Na } \\
\text { ma }\end{array}$ & K & A & D & I & R & $\begin{array}{c}\text { tal } \\
\text { to }\end{array}$ & $\begin{array}{c}\text { gate } \\
\text { gorikator }\end{array}$ \\
\hline 1 & AF & 15 & 15 & 15 & 15 & 20 & 80 & BSB \\
2 & DW & 10 & 10 & 15 & 15 & 15 & 65 & BSH \\
& T & & & & & & & \\
3 & FR & 10 & 15 & 15 & 10 & 15 & 65 & BSH \\
4 & HD & 10 & 10 & 15 & 10 & 15 & 60 & BSH \\
5 & YN & 10 & 15 & 15 & 15 & 15 & 70 & BSH \\
6 & SW & 15 & 15 & 15 & 15 & 20 & 80 & BSB \\
7 & IRF & 5 & 10 & 15 & 10 & 10 & 50 & MB \\
8 & TA & 10 & 10 & 15 & 10 & 15 & 60 & BSH \\
9 & YH & 10 & 15 & 15 & 10 & 15 & 65 & BSH \\
\hline
\end{tabular}

Tabel 2 menunjukan bahwa rata-rata siswa berada pada kategori berkembang sesuai dengan harapan (BSH). Adapun satu siswa yang masuk kedalam kategori MB adalah IRF yang mana siswa yang bersangkutan merupakan yang paling muda diantara siswa yang lain. Selain itu IRF juga merupakan pendatang yang tentu jika dibandingkan dengan yang lain yang sudah saling mengenal satu sama lain, kedekatan IRF dengan teman yang lain relatif baru terbangun. Proses ini tentu menjadi proses dimana siswa terlibat dalam pembelajaran (Bergmann \& Sams, 2012; Jamaludin \& Osman, 2014) yang merupakan salah satu kelebihan flipped learning.

Setelah selesai dengan aktifitas presentasi siswa, guru memberikan penjelasan tentang apa saja yang bisa diungkapkan dan juga memberikan contoh yang baik bagaimana cara menyampaikan sesuatu secara lisan sebagai bentuk penguatan kepada siswa agar siswa lebih memiliki kepercayaan diri ketika diberikan kesempatan untuk mengungkapkan hal yang serupa. Disamping itu, guru juga memutar ulang video yang diberikan ketika belajar secara online.

Pada tindakan kedua, guru beserta peneliti merencanakan skenario pembelajaran yang terdiri dari dua pertemuan secara online dan tatap muka. Hanya saja ada sedikit perbedaan treatment yang diberikan oleh guru sebagai bentuk revisi dari tindakan pertama, dimana pada pertemuan online tindakan kedua ini guru tidak hanya mendistribusikan video pembelajaran yang dibuat sendiri oleh gurunya, melainkan juga menggunakan video conference melalui Zoom meeting. Hal ini didasarkan pada hasil yang didapat pada tindakan pertama dimana siswa belum bisa memaksimalkan potensi mereka. Asumsi yang digunakan adalah apabila guru dan siswa secara syncronous bertemu, apa yang menjadi tujuan pembelajaran bisa disampaikan secara langsung sehinggga siswa memiliki pemahaman yang baik.

Pada pertemuan online ini, tema yang dikembangkan masih seputar diriku/diri sendiri secara lebih spesifik terkait panca indera beserta fungsinya. Pada kesempatan ini, video yang dibagikan secara khusus dibuat oleh guru. Harapannya siswa akan lebih memperhatikan detail dari video dikarenakan sosok yang ada dalam video tersebut adalah guru mereka sendiri (Bergmann \& Sams, 2015).

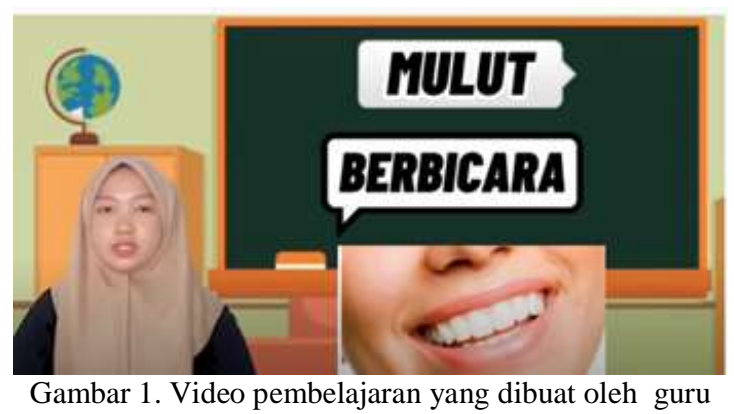

Pada pembelajaran online yang dilakukan melalui video conference, guru juga menjelaskan terkait panca indera beserta fungsinya. Hal ini dilakukan agar siswa yakin 
dan bisa menyampaikan bagian-bagian tubuh beserta fungsinya tersebut pada saat pembelajaran tatap muka. Dalam kesempatan ini juga, guru meminta siswa untuk berlatih secara mandiri di rumah masing-masing menjelaskan panca indera beserta fungsinya.

Pada pembelajaran tatap muka di tindakan kedua ini dilakukan sehari setelah siswa melakukan pembelajaran online. Seperti biasa, guru menyambut siswa dengan penuh semangat dan berharap siswa mampu mempresentasikan tugas atau pengalaman yang diberikan sebelum pembelajaran tatap muka berlangsung. Setelah berdoa dan bernyanyi dan juga melakukan aktifitas pendahuluan lainnya, guru bertanya kepada siswa apakah siswa sudah mempraktekan apa yang diminta oleh guru pada saat pembelajaran online yakni berlatih menjelaskan alat indera beserta fungsinya. $100 \%$ siswa menjawab dengan penuh semangat dan merespon guru seolah mereka tidak sabar ingin tampil kedepan. Hal ini tentu sebagai dampak pembelajaran online dan juga video pembelajaran yang diberikan yang dibuat oleh guru secara mandiri sehingga siswa mendapatkan informasi yang komprehensif terkait materi dan juga tugas apa yang diberikan.

Berdasarkan hasil pengamatan peneliti dengan menggunakan performance checklist didapatkan hasil yang menggembirakan dimana dari 9 siswa yang terlibat dalam proses pembelajaran $80 \%$ dari mereka ada dalam kategori BSB. Berbeda dengan pada tindakan pertama dimana yang masuk kategori BSB hanya dua orang siswa. Hal tersebut dapat dilihat pada tabel berikut :

Tabel 3. Keterampilan berbicara siswa pada tindakan ke 2

\begin{tabular}{|c|c|c|c|c|c|c|c|c|}
\hline & Nam & & & $\overline{\text { dik: }}$ & & & Tota & Kateg \\
\hline & a & $\mathrm{K}$ & A & D & I & $\mathrm{R}$ & 1 & ori \\
\hline 1 & $\mathrm{AF}$ & 20 & 15 & 15 & 15 & 20 & 85 & BSB \\
\hline 2 & $\begin{array}{l}\text { DW } \\
\text { T }\end{array}$ & 20 & 15 & 15 & 15 & 20 & 85 & BSB \\
\hline 3 & FR & 15 & 15 & 15 & 15 & 15 & 75 & BSH \\
\hline 4 & HD & 15 & 15 & 10 & 15 & 15 & 70 & BSH \\
\hline 5 & YN & 20 & 15 & 15 & 15 & 15 & 80 & BSB \\
\hline 6 & SW & 15 & 15 & 15 & 15 & 20 & 80 & BSB \\
\hline 7 & IRF & 20 & 15 & 15 & 15 & 15 & 80 & BSB \\
\hline 8 & TA & 15 & 10 & 15 & 15 & 15 & 70 & BSH \\
\hline 9 & $\mathrm{YH}$ & 15 & 15 & 15 & 15 & 20 & 80 & BSB \\
\hline
\end{tabular}

Tabel 3 menunjukan mayoritas siswa sudah berkembang dengan sangat baik dimana 6 siswa berada pada kategori BSB. Adapun siswa yang masih berada di kategori BSH ada 3 siswa yakni FR, HD dan juga TA. Yang paling berbeda dari tindakan pertama dan tindakan kedua adalah IRF dimana pada peningkatnnya cukup signifikan dari MB pada tindakan pertama menjadi BSB pada tindakan yang kedua. Diamping itu berdasarkan hasil observasi, siswa tersebut juga mulai settle-in dengan lingkungannya.

Selain meningkatnya kemampuan siswa dalam berbicara, pada tindakan kedua juga proses pembelajaran relatif lebih mengalir jika dibandingkan dengan tindakan pertama. Hal yang membedakan adalah siswa dan guru sudah mulai terbiasa dengan pola pembelajaran flipped sehingga ketika pembelajaran tatap muka berlangsung, siswa sudah siap untuk mendalami materi yang disajikan. Begitupun guru terlihat lebih meyakinkan dalam hal menjelaskan. Hal ini disebabkan oleh persiapan yang baik yang bisa terlihat dari video pembelajaran yang dikreasi dan juga pembelajaran online secara synchronous.

Berdasarkan hasil penelitian, flipped learning ternyata bisa diaplikasikan pada ranah anah usia dini sekalipun. Meskipun demikian ada hal-hal yang harus senantiasa diperhatikan ketika guru TK atau guru PAUD ingin mengaplikasikan pendekatan pembelajaran seperti ini. Hal pertama yang harus dilakukan oleh guru adalah melakukan persiapan secara maksimal. Persiapan sangat dibutuhkan oleh guru baik dalam pembelajaran tatap muka maupun dengan menggunakan pendekatan seperti flipped learning. Hanya saja dalam menggunakan flipped learning, guru relative lebih bekerja keras (Bergmann \& Sams, 2015) seperti mempersiapkan materi, skenario dan juga RKHS yang sifatnya administratif. Dalam hal materi, sebetulnya tidak harus berbentuk video pembelajaran (Bishop \& Verleger, 2013). Guru bisa juga memberikan materi dari sumber-sumber yang tersedia seperti dari buku ataupun sumber lainnya. keunggulan video pembelajaran tentu berbeda, terlebih ketika video pembelajaran tersebut dibuat oleh gurunya sendiri. Anakanak akan merasakan atmosfer belajar ketika 
mereka menyimak video dimana sosok guru mereka bisa terlihat.

Persiapan yang dilakukan tentu tidak hanya persiapan yang dilakukan oleh guru, melainkan siswa juga harus dipersiapkan. Hal ini terlihat dari penelitian ini bahwa ketika siswa tidak dipersiapkan secara matang, hasil yang diperoleh juga tidak maksimal. Salah satu upaya persiapan yang dapat dilakukan adalah komunikasi dengan orang tua, karena bagaimanapun akan sangat sulit untuk anak usia dini mengoperasikan aplikasi pemutar video atau video conferencing sendiri. Mereka membutuhkan bantuan dari orang tua sehingga tujuan pembelajaran bisa tercapai. Disamping itu, untuk flipped learning pada anak usia dini, peran orang tua masih sangat dominan untuk mengarahkan anak-anaknya dalam memahami materi terutama pada preclass activity. Oleh karena itu, kerja sama yang baik antara guru dan orang tua akan memaksimalkan pendekatan flipped learning di TK atau PAUD.

Hal berikutnya yang harus diperhatikan adalah keterlibatan siswa (Smallhorn, 2017). Dalam pendekatan flipped learning ini, guru diharapkan terampil dalam mendesain pembelajaran sehingga siswa bisa aktif dalam mengikuti pembelajaran. Selain itu, peran guru didalam kelas bukanlah sebagai satusatunya sumber belajar melainkan sebagai fasilitator dimana siswa menjadi titik pusat pembelajaran (student centered). Hal ini tentu harus dipahami oleh guru, agar guru bisa membuat desain pembelajaran yang didominasi oleh kegiatan-kegiatan siswa misalnya saja bercerita dan kegiatan aktif (practical) lainnya.

Pada pembelajaran online yang dilakukan melalui video conference, guru juga menjelaskan terkait panca indera beserta fungsinya. Hal ini dilakukan agar siswa yakin dan bisa menyampaikan bagian-bagian tubuh beserta fungsinya tersebut pada saat pembelajaran tatap muka. Dalam kesempatan ini juga, guru meminta siswa untuk berlatih secara mandiri di rumah masing-masing menjelaskan panca indera beserta fungsinya.

Selain persiapan dan juga keteribatan siswa yang harus menjadi perhatian guru, implementasi didalam ruang kelas juga menjadi hal yang signifikan. Hal ini agar dalam pelaksanaanya lebih maksimal dan tentu berbeda dengan pembelajaran pada biasanya. Pembelajaran dengan flipped learning haruslah dapat mengakomodir cara berfikir siswa menjadi lebih keratif dan juga inovatif.

\section{SIMPULAN}

Berdasarkan hasil penelitian dan juga pembahasan terkait peningkatan keterampilan berbicara siswa melalui pendekatan flipped learning disimpulkan bahwa flipped learning dapat meningkatkan kemampuan berbicara siswa PAUD dan tentu bisa menjadi alternatif pembelajaran yang bisa digunakan oleh guru pada tingkat pendidikan anak usia dini. Selain itu, dengan menggunakan flipped learning, keterlibatan siswa dalam pembelajaran baik online maupun tatap muka semakin terlihat karena masing-masing siswa ingin menunjukan kemampuan yang dimiliki. Walaupun demikian terdapat hal-hal yang harus diperhatikan dalam menggunakan pendekatan ini diantaranya adalah persiapan yang maksimal, pembelajaran yang harus membuat siswa terlibat, dan pembelajaran yang dapat mengakomodir siswa agar senantiasa bisa berfikir kreatif. 


\section{DAFTAR PUSTAKA}

Alsobaie, M. F. (2018). Effective Teaching and Learning: Flipped Learning in the Classroom. In Western Michigan University. Western Michigan University.

Bergmann, J., \& Sams, A. (2012). Flipped Your Classroom : Reach Every Students in Every Class Every day. In International Society for Technology in Education.

Bergmann, J., \& Sams, A. (2015). Flipped Learning for Elementary Instruction. In International Society for Technology in Education. https://doi.org/10.4135/9781483318332. n193

Bishop, J. L., \& Verleger, M. A. (2013). The flipped classroom: A survey of the research. ASEE Annual Conference and Exposition, Conference Proceedings, August. $\quad$ https://doi.org/10.18260/1-2-22585

Creswell, J. W. (2013). Research Design; Qualitative, Quantitative and Mixed Method Approaches. In SAGE Publication (4th Editio). SAGE. https://doi.org/https://dx.doi.org/10.1453 /jsas.v4i2.1313

Flipped Learning Network. (2014). What Is Flipped Learning? The Four Pillars of F-L-I-P. Flipped Learning Network, 501(c), 2.

Hung, H. (2015). Design-Based Research: Redesign of an English Language Course Using a Flipped Classroom Approach. Tesol Quarterly, 180-192. https://doi.org/10.1002/tesq.328

Jamaludin, R., \& Osman, S. Z. M. (2014). The Use of a Flipped Classroom to Enhance Engagement and Promote Active Learning. Journal of Education and Practice, 5(2), 124-131.

Kemendikbud. (2020). Surat Edaran
Pembelajaran Daring Selama Pandemi Covid 19.4-6.

Lai, C., \& Hwang, G. (2016). A Selfregulated flipped classroom approach to improving students' learning performance in a mathematics course. Computers \& Education. https://doi.org/10.1016/j.compedu.2016. 05.006.This

Ozdamli, F., \& Asiksoy, G. (2016). Flipped Classroom Approach. World Journal on Educational Technology, 8(2), 98-105.

Sahara, R., \& Sofya, R. (2020). Pengaruh Penerapan Model Flipped Learning dan Motivasi Belajar Terhadap Hasil Belajar Siswa. Jurnal Ecogen, 3(3), 419-431.

Smallhorn, M. (2017). The flipped classroom: A learning model to increase student engagement not academic achievement. Student Success, 8(2), 43-53. https://doi.org/10.5204/ssj.v8i2.381

Sun, L., Tang, Y., \& Zuo, W. (2020). Coronavirus pushes education online. Nature Materials. https://doi.org/10.1038/s41563-0200678-8

Sutarna, N., Acesta, A., Cahyati, N., Giwangsa, S. F., \& Iskandar, D. (2022). Dampak Pembelajaran Daring terhadap Siswa usia 5-8 tahun. 6(1), 288-297. https://doi.org/10.31004/obsesi.v5i2.126 5

Tao, S., Huang, Y.-H., \& Tsai, M.-J. (2016). Applying the Flipped Classroom with Game-based Learning in Elementary School Students 'English Learning. International Conference on Educational Innovation through Teachnology, 59-63. https://doi.org/10.1109/EITT.2016.19 